\title{
Obstacles to Developing Net-Zero Energy (NZE) Homes in Greater Toronto Area
}

\author{
Ghazal Makvandia ${ }^{1}$ and Md. Safiuddin ${ }^{1,2,3, *}$ \\ 1 Angelo DelZotto School of Construction Management, George Brown College, 146 Kendal Avenue, \\ Toronto, ON M5T 2T9, Canada; gmakvandia@gmail.com \\ 2 Department of Civil Engineering, Faculty of Engineering and Architectural Science, Ryerson University, \\ 350 Victoria Street, Toronto, ON M5B 2K3, Canada \\ 3 Department of Civil and Environmental Engineering, Faculty of Engineering, University of Windsor, \\ 401 Sunset Avenue, Windsor, ON N9B 3P4, Canada \\ * Correspondence: msafiuddin@georgebrown.ca
}

Citation: Makvandia, G.; Safiuddin, M. Obstacles to Developing Net-Zero Energy (NZE) Homes in Greater Toronto Area. Buildings 2021, 11, 95. https://doi.org/10.3390/buildings 11030095

Academic Editors: Ala Hasan, Francesco Reda and Umberto Berardi

Received: 5 January 2021

Accepted: 25 February 2021

Published: 4 March 2021

Publisher's Note: MDPI stays neutral with regard to jurisdictional claims in published maps and institutional affiliations.

Copyright: (c) 2021 by the authors. Licensee MDPI, Basel, Switzerland. This article is an open access article distributed under the terms and conditions of the Creative Commons Attribution (CC BY) license (https:// creativecommons.org/licenses/by/ $4.0 /)$.

\begin{abstract}
Efforts have been put in place to minimize the effects of construction activities and occupancy, but the problem of greenhouse gas (GHG) emissions continues to have detrimental effects on the environment. As an effort to reduce GHG emissions, particularly carbon emissions, countable commercial, industrial, institutional, and residential net-zero energy (NZE) buildings were built around the globe during the past few years, and they are still operating. But there exist many challenges and barriers for the construction of NZE buildings. This study identifies the obstacles to developing NZE buildings, with a focus on single-family homes, in the Greater Toronto Area (GTA). The study sought to identify the technical, organizational, and social challenges of constructing NZE buildings, realize the importance of the public awareness in making NZE homes, and provide recommendations on how to raise public knowledge. A qualitative approach was employed to collect the primary data through survey and interviews. The secondary data obtained from the literature review were also used to realize the benefits, challenges, and current situation of NZE buildings. Research results indicate that the construction of NZE buildings is faced with a myriad of challenges, including technical issues, the lack of governmental and institutional supports, and the lack of standardized measures. The public awareness of NZE homes has been found to be very low, thus limiting the uptake and adoption of the new technologies used in this type of homes. The present study also recommends that the government and the academic institutions should strive to support the NZE building technology through curriculum changes, technological uptake, and financial incentives to buyers and developers. The implementation of these recommendations may enhance the success and popularity of NZE homes in the GTA.
\end{abstract}

Keywords: buildings; construction; efficient homes; energy efficiency; GHG emissions; homes; net-zero energy (NZE); NZE building technology

\section{Introduction}

Every year, numerous commercial, industrial, institutional, and residential buildings are constructed around the world. Iyer-Raniga [1] reported that almost $235 \times 10^{9} \mathrm{~m}^{2}$ of building floor area was constructed by 2016, and an additional $230 \times 10^{9} \mathrm{~m}^{2}$ will be constructed by 2056. A large amount of energy is required to operate the buildings, which may significantly add to greenhouse gas (GHG) emissions if non-renewable energy sources are used. Ontario consumes a significant portion of primary energy in its building sector, and as a developing region, this share is estimated to continue to grow in the future due to today's fast urbanization. Buildings account for around $33.3 \%$ of the final energy demand and 30\% of GHG emissions in the globe [2]. As of 2018, buildings were the largest source of GHG emissions in Toronto, accounting for about $55 \%$ of the total community-wide emissions [3]. This is concerning with respect to the effects of GHG 
emissions on the environment. Therefore, more efficient buildings are required for energy savings and reduced environmental pollution. The goal of net-zero energy (NZE) buildings is to produce enough renewable energy to meet buildings' annual energy consumption requirements by zeroing the use of non-renewable energy [4-6], thus decreasing GHG emissions [7]. The annual onsite renewable energy for NZE buildings should be equal to or greater than the actual annual energy demand $[8,9]$. Achieving this energy condition is not very straightforward. This paper analyzes the different obstacles to constructing commercial, industrial, institutional, and residential NZE buildings across the Greater Toronto Area (GTA) with a focus on single-family homes.

NZE buildings require both energy-saving and energy-producing approaches. Passive solar design, effective building envelope, energy-efficient appliances, and renewable energy sources are essential for these buildings. The energy requirement of buildings can be reduced by orienting the structure properly so that it can gain more solar heat during the winter but less during the summer, and getting daylight is also important as it can reduce the energy spent for indoor lighting [10]. Moreover, substantial energy can be conserved using high-performance insulation in wall, floor, and roof systems [11]. Energy consumption in buildings can also be significantly decreased using energy-efficient appliances, HVAC (heating, ventilation, and air conditioning) equipment, and light fixtures [12]. On the other hand, sunlight and solar heat are commonly used as a source of renewable energy for buildings [13,14]. Besides, wind, biomass, and geothermal energy can be used for various building services [15]. The other aspects such as advanced framing, triple-pane windows, and open-web trusses are also considered for constructing NZE buildings [16].

Research on NZE buildings recognizes the importance of design and acknowledges the role of construction in the development of these buildings to reduce GHG emissions and reverse the adverse effects of global warming. Certain studies focused the design and technical requirements of NZE buildings, and how they impact the environment [17,18]. Many published works show that NZE buildings have been built in different parts of the globe, including Canada, and they are still operating $[14,19,20]$. However, in Ontario, the past research on NZE buildings mainly focused on energy consumption rather than evidence-based approaches to NZE housing in different areas, including the GTA. Necessary steps were not taken to effectively minimize foremost challenges such as technological barriers, and to increase the governmental and institutional supports for NZE homes. Also, the importance of the public awareness was somehow not prioritized. To build more NZE homes in communities, people who live in those communities and are paying to buy properties must be educated about efficient homes. More awareness will lead to an increase in demand for NZE homes. This study has examined the degree of the public awareness of NZE homes in the GTA.

Natural Resources Canada (NRC) took initiatives in 2013 to enhance the development of NZE buildings in Canada, starting with a pilot project called "The R-2000 Net-Zero Energy Pilot" [21]. The purpose was to encourage and support the Canadian construction companies to build NZE homes, and rate these homes using NRC's EnerGuide Rating System and mark them under the R-2000 standard. Thereafter, by 2016, six construction companies built twenty-three NZE homes in three provinces, including Ontario, and the feasibility of these homes on a community level in Canada was also demonstrated to increase their acceptance in the housing market [21]. With all these efforts, NRC has developed the methodology to evaluate the NZE aspects of buildings that includes modified home energy rating scale, whole house energy analysis, assessment of emerging technologies, feasibility studies, mechanisms for enabling construction industry to adopt renewable energy sources, establishment of energy model and guidelines, and field appraisal [22].

Despite the vast resources and technologies in today's construction industry, there are many challenges along the way to develop energy-efficient buildings [23]. NZE homes are built based on certain new technologies, and thus are not yet popular. It is, therefore, important to identify the constraints which may hinder the development of NZE homes. The public awareness is also important because it creates opportunities for the acceptance 
of new technology. This study first identifies and analyzes the technical, organizational, and social challenges of building NZE homes. Secondly, the study is intended to establish the importance of public knowledge in promoting NZE homes. Finally, the study aimed at providing recommendations on how to raise public knowledge on NZE homes. These recommendations, when applied, could help increase the public awareness of NZE homes and consequently eliminate some of the obstacles during implementation.

\section{Literature Review}

The intensification of commercial and residential construction within the City of Toronto and close to major transit nodes is contributing to high energy consumption and environmental degradation. Efforts have been put in place to minimize the effects of construction activities and occupancy, but the problem of carbon emissions continues to have harmful effects on the environment. To alleviate this problem, Toronto's leading developers have developed mechanisms that reduce emissions and improve the energy performance of buildings [24]. One such mechanism is the adoption of NZE technology for making homes. Various definitions of NZE homes exist but the overall concept is having a building which generates as much energy as it consumes with zero carbon emissions. Iyer-Raniga [1] defines the NZE home as a building that has annual net-zero energy consumption from the power grid and net-zero carbon emissions. NRC agrees that an NZE home focuses on producing at least as much energy as it requires on an annual basis [22]. Numerable new buildings have already been built in the GTA and other cities or towns of Ontario using NZE technology [25-27]. However, more pace is required to help the government achieve the targets of its climate action plan through reduced carbon emissions.

There are barriers for the development and construction of NZE buildings in the GTA. The lack of knowledge on how to integrate conventional electrical supply to the green energy system of the home by the electric utility company personnel may undermine the performance of energy components and systems. Pettit et al. [16] observed that NZE design requirements such as advanced framing, open-web floor trusses, high-performance wall and roof enclosure, and solar power integration need advanced skills and expertise. Piderit et al. [28] agreed that NZE home encompasses a complex system that needs skilled professionals with knowledge across different engineering, scientific, and technical disciplines. The construction industry in the GTA is still adjusting to the multi-disciplinary design approach for NZE buildings. The principal design requirement is to integrate many energy-saving and energy-producing techniques that are suitable and economically feasible for a green construction project. For this, an efficient energy use analysis mechanism helps in the projection of the total annual energy consumption of a building.

Improving energy efficiency is initially costly due to the complex technical requirements of NZE buildings. Also, the energy use in the household may vary from one place to another depending on climate conditions, thus affecting the design and development of NZE homes. Hamilton [29] reported that surveys on homes with similar energy-saving systems showed variations in energy use across different climates and regions in Canada; for example, the average annual home energy cost in Ontario is \$2358 and that in Nova Scotia is $\$ 2903$. Moreover, the initial construction cost becomes higher for NZE homes than traditional homes. The case study of NRC [22] showed that their NZE home is not yet market-feasible because of the large first cost $(\$ 100,000$ to $\$ 150,000)$ to achieve it. Initial construction costs increase significantly due to the lack of technological knowledge and industry experts who possess the technical skills and experience to maximize the benefits of passive design and install energy-producing components in homes. Hence, certified NZE home builders should be available in plenty to enhance the growth of NZE homes. But green energy developers lack an effective certification and assessment system solely for NZE housing in the GTA. Although Toronto's leading developers have developed mechanisms to decrease GHG emissions from buildings and enhance their energy performance, the study by Pettit et al. [16] revealed that Chile and Canada have challenges in 
establishing the best practices and standards for NZE homes in the construction industry. Although developers are incorporating LEED Canada (LEED means Leadership in Energy and Environmental Design) certification for homes [30], it is not specially formulated for NZE construction. Without a standardized certification system exclusively for NZE homes, the construction of these homes may fail.

Government policy plays a major role in the development and popularity of NZE homes. The City of Toronto has green standards on energy efficiency and renewable energy for low-rise residential and mid- to high-rise residential and non-residential buildings [31,32]. The City also has guidelines regarding the district energy system and operational systems for mid- to high-rise residential and non-residential development [32] — these standards and guidelines could be useful to support the development of NZE buildings in the GTA. However, McVey et al. [33] stated that regional regulations limit the ability of local distribution companies to establish district energy networks and serve as aggregators of distributed energy generation and storage resources. Their analysis of the policies indicated that the existing rules on the participation of combined heat and power projects in electricity markets create further barriers for coordinating renewable energy sources into the power system. The lack of policies supporting renewable energy development at the district level undermines the development of NZE homes. Currently, Toronto lacks NZE infrastructures that provide capital and technical support to contractors and specialists. The withdrawal of federal and provincial funding in the Port Lands project debilitated the sustainable development of NZE community buildings. The lack of capital and funding destabilizes the process of innovation in the construction industry through research and development.

Recent trends in building construction create limitations for the development of NZE housing in the GTA. The high costs of labor and land are contributing to unfavorable building design strategies [24]. For instance, developers are using low-cost building materials and minimizing their residential suite size and floor-to-floor height to address the high land and labor costs. However, these strategies have only served to minimize the costs by compromising the quality of buildings, and they are not conducive to promote NZE homes. Eliminating the barriers to NZE housing by improving micro-power grid access, easing strict permits, and enhancing the process of certification for construction companies will significantly reduce the cost of construction. Zhang et al. [23] argued that the introduction of utility energy pricing policy will offer developers realistic economic returns for energy efficiency and contribute to reducing GHG emissions. Besides, Wills et al. [34] identified NZE as a performance target, which has not been implemented by the government. The revision of Canada's energy policies and new targets for the building sector to facilitate the development of net-zero ready building codes will improve the standardization processes. In addition, facilitating the technological development through research grants will improve the quality of solar, wind, and heating technologies for use in NZE households in the GTA and other areas of Ontario. Piderit et al. [28] supported the claim that government funding provides incentives for construction experts to test new designs, products, and mechanisms in a risk-free environment.

Along with technical barriers and government policy issues, the lack of awareness among residents on the benefits of NZE homes has limited their market penetration in the GTA. People are reluctant to invest in projects whose benefits they do not clearly understand, especially in such a case where the alternative is cheaper. The results of personal interviews reported by Hamilton [29] demonstrated the lack of public education on the benefits of NZE homes in promoting energy sustainability in Ontario. Whereas more citizens are becoming conscious of their role in household energy emissions, they lack the basic information on how NZE housing can reduce GHG emissions and improve sustainability. 


\section{Methodology}

This study mostly uses a qualitative research approach to examine the barriers to the development of NZE buildings, particularly single-family NZE homes, in the GTA. Qualitative research is exploratory in nature, and hence it was better suited for this study whose main aim was to identify the obstacles for NZE homes by gathering information from the public and building experts. Surveys and interviews were used to collect information on the degree of the public awareness of NZE homes. Major barriers or challenges were identified largely from the interview results and considerably from the survey data. The data collected were mainly subjected to descriptive analyses to provide an overall picture of the research findings. The significance of the survey data was also judged using statistical means. The overall methodology is schematically shown in Figure 1.

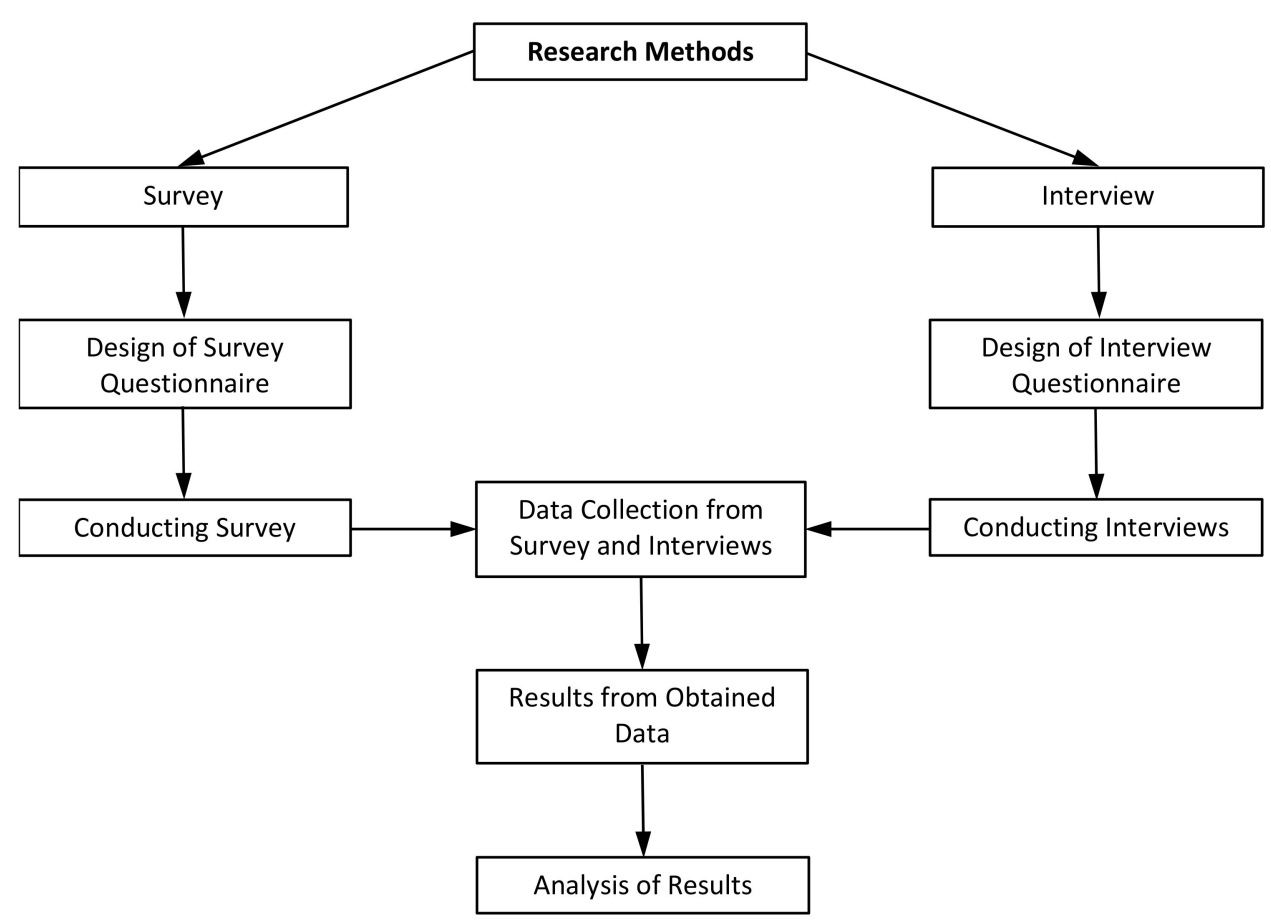

Figure 1. Overall research methodology.

\subsection{Survey}

This study used survey as a primary method of data collection to achieve the research objectives. Survey allows to gather more data for nonexperimental researchresearchers describe the findings by observing the collected data and analyzing how variables are related to each other [35]. It is also widely used in nonexperimental building research $[12,29,36]$. For the present study, the survey questionnaire comprising nine questions (without any abbreviations), as shown below, was distributed through SurveyMonkey. The link for the survey questionnaire was also shared on LinkedIn. More emphasis was given on NZE homes while designing the questionnaire for survey.

(1) What is your age? Please indicate.

(2) What is your occupation? Please select the best answer.

(3) How would you describe your household annual income?

(4) How much do you know about net-zero energy homes?

(5) Would you be interested to purchase a net-zero energy home?

(6) If you are interested to purchase a net-zero energy home, do you think the Ontario government would support that financially?

(7) Would you be willing to pay extra for a home that helps keep our environment greener?

(8) Do you think net-zero energy homes will help our environment? 
(9) If you already have a house, would you be interested to install solar panels on your roof?

For the sake of clarity and the ease of analysis, close-ended questions were used to obtain information from the survey participants. The participants included varying categories of people in terms of age, occupation, and financial status. The survey collected information on age, occupation, income level, knowledge on NZE homes, the views on government involvement, and the level of interest in NZE homes among participants. The respondents fell within the range of 18 to over 65 years of age with variable household incomes.

According to Statistics Canada's 2016 Census, the total population of the GTA in 2016 was 5,928,040; among them, the population in the age range of 25-64 years was 3,305,380 (55.76\%) and the working population with various occupations was 3,286,350 (55.44\%) [37]. The employed population might have the financial capability to buy a home, as most of them are probably earning annually $\$ 50,000$ and above. Indeed, they are the main driver for the growth of NZE homes in the GTA, because they are most capable of buying these homes due to their economic solvency. Therefore, this population was considered in the present study to determine the sample size. The necessary sample size was calculated based on the following Equation (1) [38,39]:

$$
n=\frac{N z^{2} p(1-p)}{e^{2}(N-1)+z^{2} p(1-p)}
$$

where,

$N=$ Population size (employed population)

$n=$ Required sample size

$p=$ Expected population proportion (prevalence)

$z=$ Statistical parameter ( $z$-score) for a confidence level (CL)

$e=$ Margin of error (level of precision)

The value of $p$ needs to be estimated before conducting any new survey. To get a larger sample size, researchers should use 0.5 as an estimate of $p$ [39-41]. The $z$-score depends on CL: it is 1.65 for $90 \%$ CL, 1.96 for $95 \%$ CL, and 2.58 for $99 \%$ CL [42,43]. In survey research, 95\% CL is commonly used; however, $90 \%$ and $99 \%$ CLs are also used depending on the type of survey work [44,45]. For a survey that deals with a smaller sample size, a $90 \%$ CL is acceptable [42,44]. Moreover, a margin of error $(e)$ needs to be assumed to calculate the sample size from Equation (1). The commonly used range for the margin of error is $1-5 \%$ [45], but it can be in the range of $1-10 \%[42,44,46]$. In some cases, the margin of error can be even more than $10 \%$. Naing et al. [41] mentioned that researchers may use a larger margin of error (e.g., $>10 \%$ ) in the case of a preliminary study and where there is a resource limitation. In the present study, a 10\% margin of error at $90 \%$ CL was specified to calculate the sample size. For this margin of error, the necessary sample size found from Equation (1) was 68. However, it should be mentioned that this sample size was found using $p=0.5$, which maximizes the sample size. A smaller sample size will be obtained when $0.5<p<0.5$ [41], which practically can occur in survey work. Also, the sample size will be reduced if a margin of error $>10 \%$ is allowed [47].

\subsection{Interview}

This study used interview as another method of data collection to attain the research objectives. Interview is an important method of data collection for research, where researchers typically gather data through verbal communication with the participants [48]. This technique is also used in building research [49,50]. For the present study, three interviews were conducted that targeted professionals in the construction industry who have strong backgrounds and experience in the design and construction of NZE buildings. Candidates were selected based on the number of years of experience, exposure to the fundamental elements of design, and application of those elements to the construction of buildings. Andrew Bowerbank and Tony Cupido are two of the interviewees who 
played critical roles in the Mohawk College project, "The Joyce Centre for Partnership and Innovation", one of the few recently known projects with the focus of committing to high performance targets like NZE and zero emissions [26]. They were interviewed over the phone. Andrew Bowerbank is a former Executive Strategist at EllisDon, Mississauga, Ontario, for sustainability, energy, and innovation. Tony Cupido, Ph.D., P.Eng., is a Research Chair, Sustainability at Mohawk College, Hamilton, Ontario, and led the planning, design, construction, and early operation of the Joyce Centre for Partnership and Innovation. The other interviewee was Adrian Wang, who worked as the former Director of Innovation and Sustainability at Tridel, which is a leading developer in the GTA. The interview with Wang was conducted in person during the tour of one of the first residential NZE suits built in Toronto.

The interviews were guided by the nine key questions, as listed below, but more elaborate information was gathered through probing questions. The questionnaire for interviews was designed giving more focus on public knowledge and challenges regarding NZE buildings (e.g., single-family homes):

(1) How would you describe NZE buildings?

(2) Name key benefits of NZE buildings.

(3) From your experience, do you believe the public have a good knowledge of this subject?

(4) How do you describe the role of the government and academic institutions to advertise sustainability?

(5) How do you think we can improve public knowledge?

(6) Tell me about the challenges of designing NZE buildings?

(7) Tell me about the challenges of constructing NZE buildings?

(8) Can you tell me about the financial impact on the investors? What is the average payback of the additional costs?

(9) Where do you see the future of NZE buildings?

\section{Results}

The results obtained from the survey are presented in Figures 2-10. These are further explained in the text referring to the corresponding figure. Additionally, the results obtained from the interviews are presented as text paragraphs with each question in the interview covered separately. Section 4.1 hereafter presents the survey results while Section 4.2 presents the results of the interviews.

\subsection{Survey Results}

There were 58 survey respondents who answered all the survey questions, though the expected number was more than 68 , which is required for a $10 \%$ margin of error at $90 \%$ CL. This is $85.3 \%$ of the necessary sample size (e.g., 68). Moser and Kalton [51] stated that the results of a survey can be biased and of minimal value if the response rate is $<30-40 \%$. Hence, the above respondent number was considered acceptable for the analysis of the survey results. The actual margin of error was calculated for the obtained survey data using the following Equation (2):

$$
e=z \sqrt{\frac{p(1-p)}{n}}
$$

where,

$n=$ Sample size, it is 58 in this study

$p=$ Expected population proportion (prevalence), a value of 0.5 has been assumed

$z=$ Statistical parameter (z-score) for a confidence level (CL), it is 1.65 in this study

$e=$ Margin of error (level of precision)

The margin of error obtained from Equation (2) is $10.8 \%$ at the $90 \%$ confidence level. In terms of standard error (margin of error $/ z$-score), it is $6.6 \%$. These error values are obtained 
for $p=0.5$. The level of error decreases with the larger sample size and higher response rate [52]. If the number of the respondents were 68, which is the calculated sample size, the margin of error would have been $10 \%$, as specified. Moreover, the positiveness of the people and their greater participation in a survey lessen the level of error with increased response rate. For instance, considering the response rate of $85.3 \%$ based on the necessary sample size, if $p=0.853$ instead of $p=0.5$ is used in Equation (2) for $n=58$, it gives $7.6 \%$ margin of error, which is equivalent to $4.7 \%$ standard error. Nevertheless, to reduce the level of error, the authors conducted several interviews in addition to the survey. It was also done to ensure the reliability of the survey data. Indeed, the interview and survey results were consistent for related questions, particularly in the viewpoint of the public awareness, and no serious discrepancies were observed.

\subsubsection{Age Distribution of Participants}

The respondents were divided into seven groups based on their age, as shown in Figure 2. The percentages of the respondents for different age groups were as follows: $0 \%$ (under 18 years), $13.79 \%$ (18-24 years), 39.66\% (25-34 years), 25.86\% (35-44 years), 10.34\% (45-54 years), $5.17 \%$ (55-64 years), and $5.17 \%$ (65+ years).

Q1: What is your age? Please indicate.

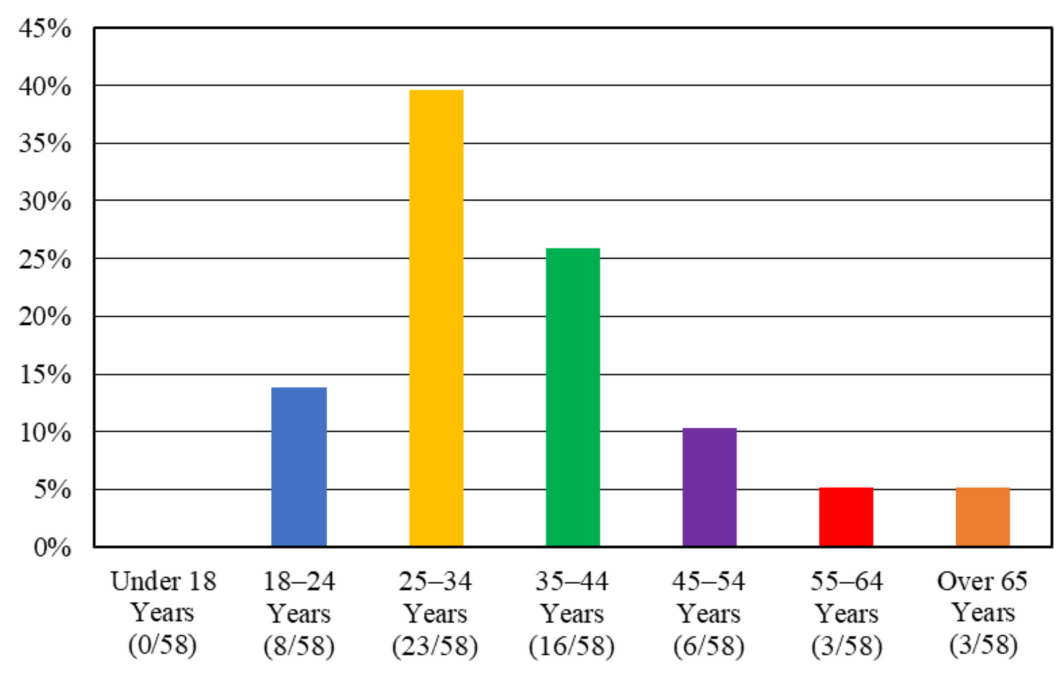

Age (No. of respondants)

Figure 2. Participants' age distribution.

The few respondents $(5.17 \%)$ who were aged above 65 years may not be really interested in new home ownership since most of them are already settled in their retirement homes and moving homes may be quite inconvenient for them. Consequently, they may not be interested in NZE homes.

\subsubsection{Occupation of Participants and Potential Home Buyers}

Potential homebuyers constituted the largest percentage (32.76\%) of the sample, as can be seen from Figure 3. This number represents the respondents from the various age brackets planning to buy homes in the future. Developers and professors constituted the smallest percentages of the samples with $1.72 \%$ and $3.45 \%$, respectively. Of the respondents, $25.86 \%$ were students, $10.34 \%$ were consultants, and $25.86 \%$ were construction professionals. The respondents may fall into multiple categories. However, the question regarding occupation only allowed each of them to choose one category, which best describes them. 
Q2: What is your occupation? Please select the best answer.

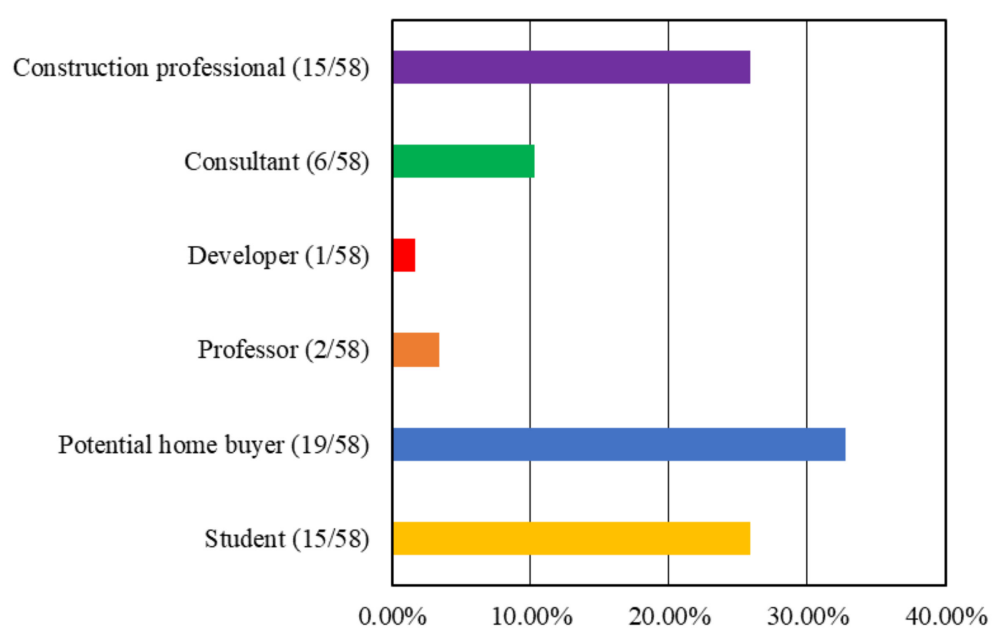

Figure 3. Participants' occupation and potential home buyers.

\subsubsection{Annual Income of Participants}

The respondents came from varying financial categories. Most of the respondents (53.44\%) were in the upper categories (\$75,000 and above), as shown in Figure 4 . The respondents with earning below $\$ 15,000$ annually constituted the smallest fraction (5.17\%) of the sample. A section of the respondents (13.79\%) earns above $\$ 150,000$ per year. The middle-income group earning between $\$ 50,000$ and $\$ 74,999$ made up $17.24 \%$ of the sample. Of the respondents, $24.13 \%$ earn between $\$ 15,000$ and $\$ 49,999$ per year.

Q3: How would you describe your household annual income?

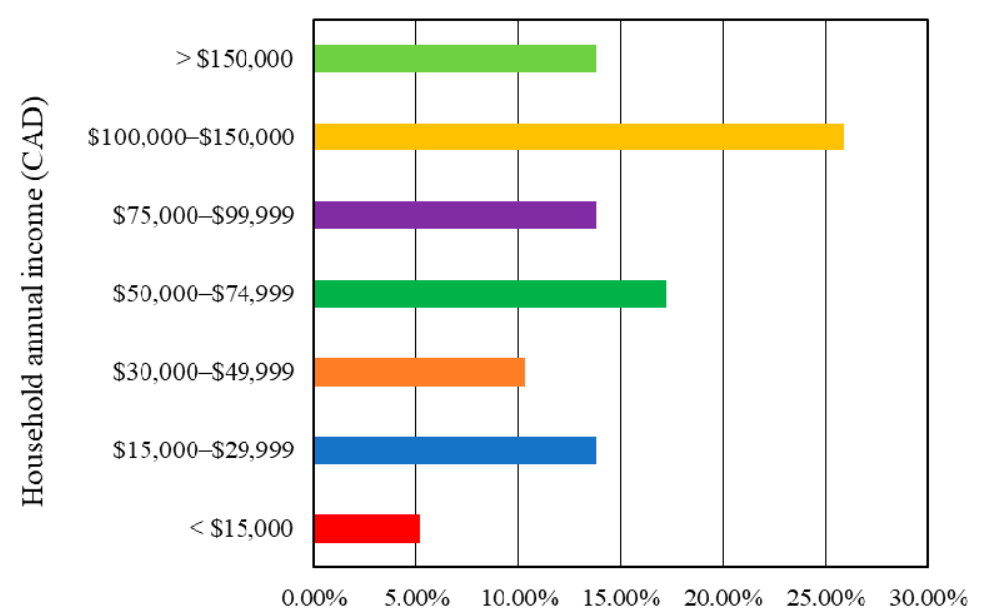

Figure 4. Participants' annual income (amounts are in Canadian dollars).

\subsubsection{Knowledge of Participants on NZE Homes}

The respondents had varying knowledge levels on NZE homes. Only $17.24 \%$ of the survey sample was sufficiently familiar with the concept of NZE homes, with only $6.90 \%$ stating that they were extremely familiar with these efficient homes, as can be seen from Figure 5. On the other hand, $22.41 \%$ of the sample had no idea about NZE homes. 
Q4: How much do you know about net-zero energy homes?

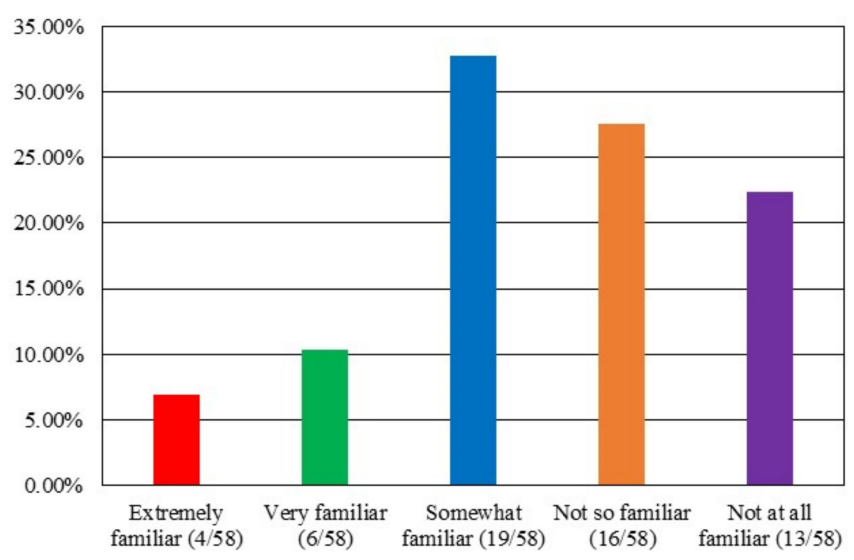

Figure 5. Participants' knowledge on net-zero energy homes (degree of familiarity).

\subsubsection{Level of Interest of Participants in NZE Homes}

The respondents' level of interest in buying NZE homes is shown in Figure 6. Among the respondents, $10.34 \%$ and $29.31 \%$ were extremely interested and very interested, respectively. Half of the respondents were somewhat interested in NZE homes, whereas 5.17\% were not so interested and another $5.17 \%$ were not at all interested. In total, $39.65 \%$ of the participants were greatly interested in NZE homes.

Q5: Would you be interested to purchase a net-zero energy home?

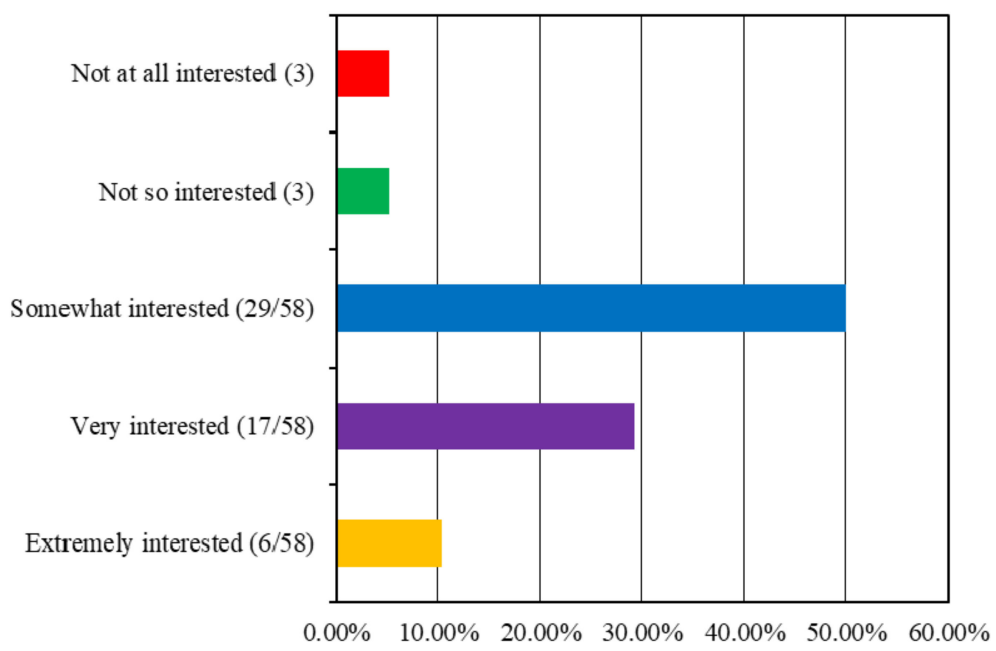

Figure 6. Participants' interest in NZE homes (degree of purchase interest).

\subsubsection{Thought of Participants on Governmental Support for Purchase of NZE Homes}

In the survey questionnaire, the respondents were asked whether they think the government would support individuals interested in buying NZE homes or not. The survey results are shown in Figure 7. Of the survey respondents, 39.66\% said 'yes', $22.41 \%$ said 'no', while $37.93 \%$ said 'I do not know'. The overall data confirm that many people believe they would get governmental support to purchase NZE homes, while a significant portion thinks they will not get such support. 
Q6: If you are interested to purchase a net-zero energy home, do you think Ontario government would support that financially?

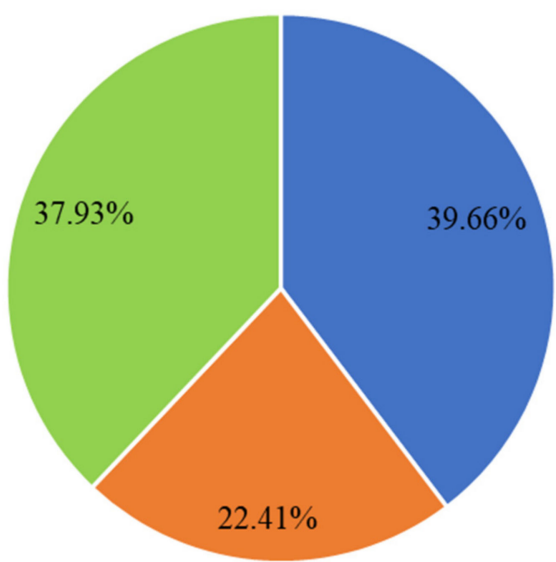

- Yes (23 Respondants) " No (13 Respondants) " I do not know (22 Respondants)

Figure 7. Participants' thoughts on governmental support towards purchase of NZE homes.

\subsubsection{Willingness of Participants to Pay More for NZE Homes}

NZE homes require extra installations that would lead to additional costs on the home. The respondents were asked whether they would be willing to pay more for these homes or not, and the majority $(74.14 \%)$ said 'yes', while the rest $(25.86 \%)$ said 'no', as can be seen from Figure 8. Although many respondents were not interested initially, they became willing to pay more for NZE homes after knowing the benefits of NZE technology.

Q7: Would you be willing to pay extra for a home that helps keeping our environment greener?

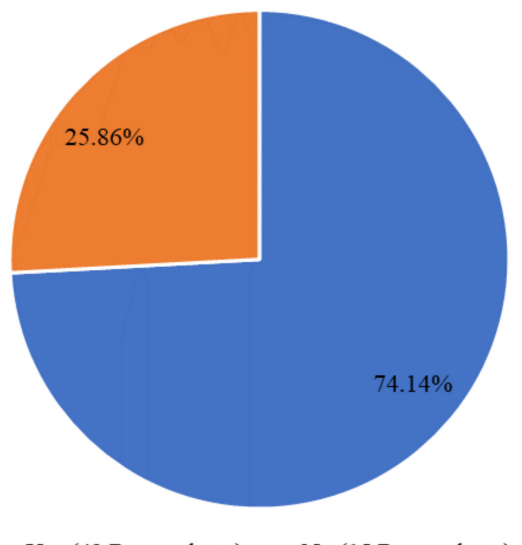

- Yes (43 Respondants) = No (15 Respondants)

Figure 8. Participants' willingness to pay more for NZE homes.

\subsubsection{Thought of Participants on Environment-Friendliness of NZE Homes}

After explaining the concept of NZE homes, the respondents were asked whether they agree or not that these homes would help protect the environment. Among the respondents, $22.41 \%$ were neutral — they neither agreed nor disagreed—while the rest fully agreed that these homes would help save the environment, and $29.31 \%$ agreed strongly while $48.28 \%$ agreed, as can be seen from Figure 9. 
Q8: Do you think net-zero energy homes will help our environment?

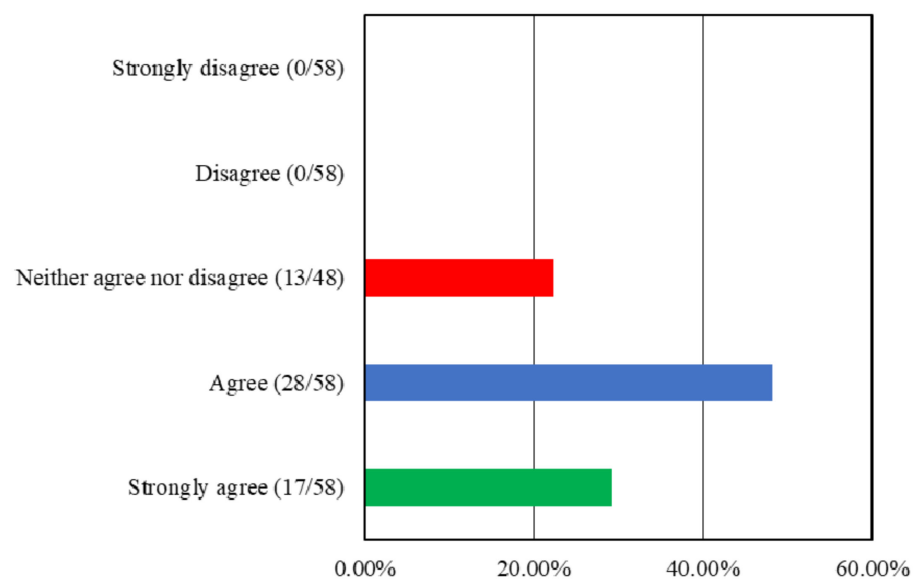

Figure 9. Participants' agreeance or disagreeance on environment-friendliness of NZE homes.

\subsubsection{Interest of Participants in Installation of Solar Panels on Existing Homes}

After explaining the concept of solar panels, the respondents who own homes were asked whether they would consider installing solar panels on their homes or not. The majority were clearly interested, as can be seen from Figure 10. Of the respondents, $24.14 \%$ and $20.69 \%$ were extremely interested and very interested respectively, with $32.76 \%$ responding that they were somewhat interested. However, $6.9 \%$ were not so interested, and $1.72 \%$ were not interested at all. Also, $13.79 \%$ answered that it is not applicable for them. The respondents may have varying energy requirements and they might also understand green energy differently. These variations may bring about the differences in their interests in solar energy.

Q9. If you already have a house, would you be interested to install solar pancls on your roof?

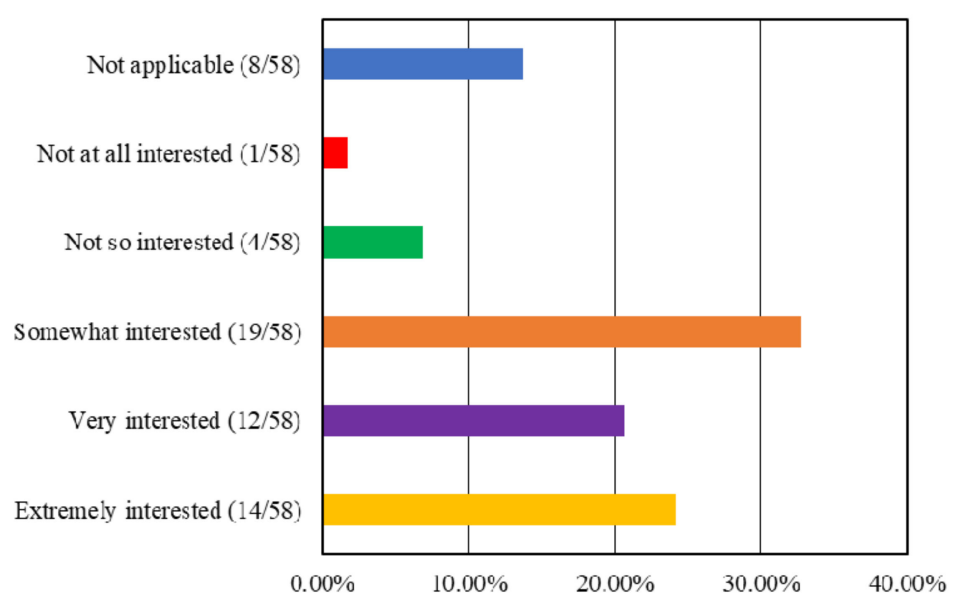

Figure 10. Participants' interest in installation of solar panels on their homes.

\subsection{Interview Results}

The three interviewees revealed a range of information from a professional perspective regarding various aspects of NZE buildings. The information gathered provides some valuable insight into this new building technology. The interview results are summarized in the following sections. 


\subsubsection{Definition of NZE Buildings}

When the interviewees were asked what is meant by NZE buildings, the responses culminated in one definition: a building that produces as much energy as it consumes annually, which is consistent with the definitions discussed in Liu et al. [6] and the one given by Iyer-Raniga [1]. In defining "net-zero", the "net" is measured annually since there are peaks and troughs in both production and consumption of energy in different seasons of the year; thus, they balance out when an annual analysis is done.

\subsubsection{Key Benefits of NZE Buildings}

The most important benefit mentioned by all interviewees is that NZE buildings do not consume any energy from the local power grid. This means that a power utility bill is eliminated when occupying an NZE home. Besides, they stated that an NZE home is a net-zero carbon building as well. This is because the house relies entirely on the green energy generated on-site and does not require any additional energy from the power grid, thereby eliminating any possibility of using non-renewable energy whose manufacture and consumption lead to carbon emissions [53]. NZE homes contribute to the long-awaited distribution grid systems. Power is generated and distributed from different points, thus decentralizing the power grid. NZE requires buildings to be constructed in a high quality and efficient manner, thus leading to homes that guarantee better occupant health, better building performance, and increased durability and longevity of the building.

\subsubsection{Public Knowledge on NZE Homes}

The interviewees agreed that the public lacks knowledge on NZE homes, which was also obvious from the survey results (refer to Section 4.1.4 and Figure 5). They stated various probable reasons, including the lack of interest, the high technicality of these buildings, poor sales and marketing strategies, slow adoption of the technology by the industry, and the newness of this technology. Additionally, it was hinted that construction companies are limited by capital incentives as to how far they can spread their wings. Therefore, most construction companies are localized, and consequently, new technologies may not expand to other areas.

\subsubsection{Role of Government and Academic Institutions to Advertise Sustainability}

The interviewees feel that the government is not doing enough to incentivize the public towards newly developed NZE homes, although in general, many people believe they would get governmental support to purchase this type of home (refer to Section 4.1.6 and Figure 7). The use of green energy has been widely identified as an effective way to protect the environment. However, efficient homes had not been upheld by the government, particularly the provincial or local municipal government, as essential efforts towards environmental protection despite their clear benefits. Additionally, academic institutions have been slow in the uptake of NZE technology despite their clear advantage over other institutions to raise the public awareness. Training institutions have the capacity to build NZE buildings to be used as demonstration centers while incorporating different modules of NZE homes in their curriculums to train the future generations of developers and construction experts on this technology.

\subsubsection{Measures for Improving Public Awareness}

On ways to improve the public awareness of NZE homes, the building experts stated that it might not be very easy. They stated that creating mass acceptance may be quite challenging. The public awareness can only be created gradually and patiently. Climate change advocacy groups can incorporate green homes as part of their suggested solutions to climate change issues. At the same time, educationists can teach NZE building technology in colleges, universities, and other training institutions to cultivate the acceptance in learners so that they can apply this when their time comes. 


\subsubsection{Challenges of Designing and Constructing NZE Buildings}

The interviewees stated that there were not any significant challenges reported regarding the design of NZE buildings. However, the lack of skills and professional capacity was mentioned as one of the major problems in the construction process. This is consistent with the challenges and barriers reported by McNabb [54]. One of the building experts stated that, for a successful project, every player must understand the importance of quality, specificity, and the variation of NZE homes from conventional buildings to play his or her part as per expectation. This understanding is currently lacking in the industry.

\subsubsection{Financial Impact on the Investors}

There are additional costs in the construction of NZE homes. It translates to a higher market price when compared to a similar conventional home, and this is consistent with what Hamilton reported in the past [29]. His report revealed that new homebuyers would need to spend at least $\$ 35,000$ more for a single-family NZE home. However, the extra cost will be catered for by the savings on energy, which will be realized by the occupant over time. One of the building experts pointed out that the payback on the extra cost will depend on how the occupant uses the energy-efficient features of a house and live on NZE, thus eliminating the cost of home energy. Also, another building expert indicated that the payback period on the extra cost will significantly decrease if more units of NZE homes are built.

\subsubsection{Future of NZE Buildings}

On the future of NZE buildings, the building experts projected that the technology would spread and be widely adopted. One of the interviewees mentioned that many of his colleagues in colleges and universities are designing net-zero energy or zero-carbon buildings. More people will focus on energy conservation, NZE, and net-zero carbon, thus increasing the popularity of NZE homes. Consequently, it will bring forth enormous energy savings and mitigate GHG emissions. Such positive impacts were also discussed by Feng et al. [55] in the context of China. They predicted that the overall primary energy savings in the range of 270-320 million tons of coal equivalent (Mtce) annually in 2030 and 740-1060 Mtce annually in 2050 will be achieved in China, mostly through energy efficiency measures.

\section{Analyses of Survey and Interview Results}

\subsection{Participants' Age Distribution}

The participants were in the age range of 18 to over 65 years. The respondents aged between 18 and 24 years are naturally expected to be students or in their entry careers. They may have varying degrees of knowledge about NZE homes, depending on their field of education, expertise, and exposure. Individuals aged between 25 and 44 years are expected to be the first-time or potential homebuyers. These are the people who may have a plethora of knowledge on homeownership, including prices and new developments in the industry. Hence, the people in the age groups of 25-34 and 35-44 years shall be more interested in purchasing NZE homes. Participants aged between 45 and 54 years are most likely homeowners and already settled down. But they may be termed as potential homebuyers if they plan to buy other residential properties. They have gained quite an experience in homeownership and the real estate business. Some from this age group may decide to purchase an NZE home. Individuals aged over 54 years of age may not have vast experience and knowledge in NZE homes because they are relatively new in the housing market. However, some of them, especially those in the construction and real estate industries, may be well-versed with the idea, and go for purchasing an NZE home.

\subsection{Participants' Occupation and Potential Home Buyers}

Participants fell into different occupational categories. However, participants may have fallen into multiple categories, but the study limited each participant to one category. 
The participants were to choose what describes them best. Potential homebuyers (32.76\%) represent the respondents from the various age brackets and economic statuses planning to buy homes in the future. These are mostly people in the age groups of 25-34 and 35-44 years who are already working, probably in their early career years or those who have been working but have not yet managed to buy homes. These individuals may be professionals in different fields. The respondents who identified themselves as consultants and construction professionals may also be potential homebuyers.

\subsection{Participants' Annual Income}

The survey participants were from different financial categories. The different financial abilities indicate the disparity in the purchasing power of individuals. An individual's financial ability dictates the kind of housing $\mathrm{s} /$ he would consider and the features that would make up such an individual's ideal housing. Most participants (53.44\%) have an annual income above $\$ 75,000$. These individuals could be more interested to purchase NZE homes due to their higher financial ability.

\subsection{Participants' Knowledge on NZE Home}

Most participants had not enough knowledge on NZE homes, as can be seen from Figure 5. Among the respondents, $32.76 \%$ were somewhat familiar and $27.59 \%$ were not so familiar with NZE buildings. Only $17.24 \%$ knew most about NZE homes, and many of these individuals are probably consultants and construction professionals. Most of them are in the age groups of $25-34$ and $35-44$ years. Furthermore, $22.41 \%$ of the respondents were totally unaware of NZE homes. Many of this group may not be interested in these energy-efficient homes unless they rightly know their benefits.

\subsection{Participants' Level of Interest in NZE Homes}

The participants had varying degrees of interest in buying NZE homes, as obvious from Figure 6. The degree of interest may vary according to the degree of awareness and understanding of the concept of NZE homes. Among the respondents, 39.65\% were highly interested in NZE homes. These people perhaps know and understand NZE homes and the benefits of having such a home, possibly because of their building-related occupation (e.g., consultants, construction professionals). They are likely to be in the age groups of 25-34 and 35-44 years. Moreover, many participants were slightly interested in NZE homes and they comprise the largest segment $(50 \%)$, as can be seen from Figure 6 . They may have an idea of what NZE homes are all about but have not understood the concept clearly. Some of them may shift their interest once they fully understand the concept of NZE homes. Those who were not so interested and disinterested collectively constituted $10.34 \%$ of the individuals participated in the survey. They are the smallest in number, as evident from Figure 6. The lack of awareness is a major contributing factor to the lack of interest.

\subsection{Participants' Willingness to Pay More for NZE Homes}

The initial cost of purchasing NZE homes is higher compared with conventional homes [29]. But most of the individuals who participated in the survey became willing to pay more for NZE homes when they were informed of the benefits of having these homes. It is evident from Figure 8 that $74.14 \%$ of the respondents became willing to spend more money for purchasing an NZE home. They are mostly from the age groups of 25-34, 35-44, and $45-54$ years, with an annual income of $\$ 50,000$ and above.

\subsection{Participants' Thoughts on Environmental Friendliness of NZE Homes}

The idea of NZE homes was brought up as a way of protecting the environment from harmful GHG emissions and exploitation of natural resources [24]. NZE homes produce as much energy as they consume [4]. Also, NZE homes produce energy from renewable sources, such as sunlight and solar heat, and they consume less energy [11-13]. After knowing these facts, $77.59 \%$ of the participants agreed that NZE homes are environmen- 
tally friendly, as obvious from Figure 9. This number would rise with the appropriate dissemination of knowledge and enhanced public awareness of NZE buildings.

\subsection{Participants' Willingness to Install Solar Panels}

One way of achieving NZE homes is through using solar energy [13,14]. Solar panels convert solar energy (e.g., sunlight) into electrical energy. This is a comparatively new technology. Earlier on, the use of solar energy was not commonly applied in residential construction. Therefore, the owners of old homes can only take the advantage of solar energy through the installation of solar panels. After knowing this fact, most of the respondents $(77.59 \%)$ became interested in installing solar panels on existing homes, as evident from Figure 10. These individuals are mostly different professionals who are earning annually $\$ 50,000$ or more and prepared to install solar panels. Within the remaining $22.41 \%, 8.62 \%$ were not interested and $13.79 \%$ said that it is not applicable to them. Some of these individuals might not need solar panels depending on where they are living, while the others may not have the financial capability to install these panels.

\subsection{Definition of NZE Homes}

Various definitions exist to describe the concept of NZE home [4,6]. The three experts interviewed defined NZE homes as buildings that produce as much energy as they consume and agreed that these homes are either zero- or low-carbon as well. However, Andrew Bowerbank noted that net-zero is an ideal measure, but the idea is to come as close to this as possible. The primary benefit stated for these buildings is that they use minimal to no energy from the power grid, and thus significantly reduce the energy cost. On the other hand, Tony Cupido, a building expert, stated that sometimes an NZE building may add some energy to the power grid if it produces more renewable energy than it consumes.

\subsection{Challenges Faced in Design and Construction of NZE Homes}

Various challenges exist against the development and construction of NZE homes in the GTA. They are discussed below.

\subsubsection{Technological Barriers}

The interviewed experts pointed out the lack of technological know-how as a major challenge faced in the construction of NZE homes. This corroborates Piderit et al. [28], who observed that NZE home involves an intricate system that requires competent professionals with experience across various engineering, scientific, and technical fields. The common challenges in design and construction include finding the right interdisciplinary team as well as getting suppliers to deliver the specific materials or products as required for NZE homes. This is because the idea is quite new and qualified professionals educated with NZE building technology are not yet abundantly available in the construction industry. The deficit of knowledge on how to integrate the regular electrical supply with the green energy system of homes by the electric utility company staffs may emasculate the performance of energy components and systems. The principal design requirement is to integrate many energy-saving and energy-producing techniques that are suitable and economically feasible for a particular construction project. Pettit et al. [16] asserted that net-zero design requirements such as advanced framing, high-performance wall and roof assemblies, openweb floor trusses, and solar power integration require advanced competences and expertise. For this, architects and engineers should be well-versed with NZE building technology before applying it to make homes. Also, the trade people need to be trained beforehand for the installation of various elements and systems of NZE homes.

Along with a construction team comprising various professionals with different expertise, advanced materials and products with good quality are required for constructing NZE homes. For example, solar units (e.g., solar panel, solar tile or shingle, photovoltaic glass) are intended to be used for generating green electricity $[13,14,56]$. The manufacturers should have adequate knowledge for producing these advanced products. The contractors 
should also know enough about NZE building technology. Moreover, for the economic use of such products, the total energy requirement for a home needs to be known. An effective energy use analysis mechanism helps in the prediction of the total yearly energy consumption of a house. By executing Building Information Modeling (BIM)-based energy performance analysis, it is possible to optimize the energy consumption of a house [57]. Trained professionals and special software (e.g., Autodesk Revit, Green Building Studio, EnergyPlus) are required to fulfill this purpose.

\subsubsection{Lack of Governmental and Institutional Supports}

The interviewees stated that both the government and academic institutions have a role to play in improving NZE homes. They think that the government should provide good support to individuals interested in buying NZE homes. This may be attributed to the fact that NZE homes are not popular amongst the public and therefore, the government intervention is required. According to McVey et al. [33], the existing regulations on the participation of combined heat and power projects in electricity markets create barriers for coordinating renewable sources into the energy system. Federal and municipal policy frameworks ought to eliminate the capital and financial barriers to the construction of NZE homes. According to an interviewee, Tony Cupido, the provincial and local municipality governments have been less supportive of energy-efficient buildings than the federal government. In the GTA, the City of Toronto has established green standards on energy efficiency and renewable energy with limits of GHG emissions in the cases of low-rise and mid- to high-rise residential as well as non-residential buildings [31,32]. Low-carbon district energy system for mid- and high-rise buildings is also addressed in one of these green standards [32]. However, regional regulations constrain local distribution companies from establishing district energy networks and serving as collectors of distributed energy generation and storage resources [33]. The lack of policies for enhancing renewable energy at the district level undercuts the development of NZE buildings. Furthermore, singlefamily homes are not yet focused by the green standards of Toronto. Hence, the government policies supporting the growth of NZE homes in the GTA are necessary. According to an interviewee, Andrew Bowerbank, the government should listen more to the industry to develop the frameworks and regulations for the advancement of NZE homes.

Academic institutions have recognized the need for change in curriculums, but it seems to be a lengthy and complex process and is taking a long time just to change some of the curriculums. According to Tony Cupido, this is unacceptable, and the colleges and universities should move quicker to adopt to the industry needs and what the marketplace demands. Academic institutions need to do more and should be more progressive. On the other hand, Andrew Bowerbank, an interviewee, thinks the colleges and universities focus on sustainability as much as they can. Academic institutions can build the buildings to demonstrate NZE technology, and they can also access the funds required to accomplish these projects, which are happening now, as he said. According to him, academic institutions "are the conduit to train the next generation of professionals, the millennial generation, or the one coming after". Colleges and universities should understand the impacts of climate change and the importance of green economy as soon as possible, and act accordingly to educate the people.

The survey results revealed that many participants (37.93\%) do not know whether they will get the governmental support or not for purchasing NZE homes. This may be due to the lack of public knowledge and inadequate distribution of information regarding the government's programs on NZE technology. However, a significant portion (22.41\%) of the participants said that the government will not support them (refer to Section 4.1.6 and Figure 7) to buy an NZE home. Two interviewees also pointed out that the government is not adequately supportive of NZE homes: Adrian Wang said, "For the consumers there are really no funds available to purchase a more energy-efficient unit." However, Canada Mortgage and Housing Corporation (CMHC) gives a rebate of up to $25 \%$ on the CMHC mortgage loan insurance premium when an individual buys or builds an energy-efficient 
home (new home) or buys an existing home and makes energy-saving renovations [24,58]. At present, some rebates and incentives are also available for Toronto homeowners through a multi-partner program "BetterHomesTO" launched by the City of Toronto on 5 November 2019 [59] to help the residents undertake home energy retrofits.

There are no incentives and rebates currently from the City of Toronto to encourage people to purchase new NZE homes. This is perhaps due to the reason that the City first wants to transform the existing homes (old homes) to the net-zero emissions level as they are collectively consuming more energy and emitting more GHG. The City Council of Toronto professed a climate emergency on 2 October 2019 and urged that the City should comply with net-zero emissions by 2050 or earlier. The City wants all new homes to be built to net-zero emissions by 2030 and all existing homes to be retrofitted to net-zero emissions by 2050 [60]. To achieve the target of net-zero emissions from buildings, attractive incentives and rebates should also be available for Toronto homebuyers to go for new NZE homes.

\subsubsection{Lack of Public Awareness}

The survey results revealed that NZE homes were not well-known to many people, as can be seen from Figure 5. This is probably because the concept of NZE homes is relatively new. It has started as an effort towards climate change adaptation. The interviewed building experts agreed that the public lacks enough awareness of NZE homes. They stated that the public is not familiar with energy-efficient homes except for a few people and the fact that it is difficult to create significant awareness among the public. It was observed from the survey results that $82.76 \%$ of the participants were not well-familiar with NZE homes (refer to Section 4.1.4 and Figure 5). Also, $60.34 \%$ of the survey respondents were not fairly interested in NZE homes (refer to Section 4.1.5 and Figure 6). In these perspectives, it should be mentioned that $25.86 \%$ (from Section 4.1 .2 and Figure 3 ) of the survey participants were construction professionals. In general, these data conclude that the public is not quite familiar with NZE homes. Such lack of the public awareness of NZE homes has limited their market penetration. The report of Hamilton [29] also revealed that the lack of public knowledge on NZE homes is acting as a barrier for promoting energy sustainability in Ontario. The conception of NZE homes was introduced as a means of minimizing the exploitation of natural resources and protecting the environment from detrimental GHG emissions. Most of the survey respondents agreed that these homes would help save the environment. Nevertheless, although more citizens are becoming conscious of their role in household energy emission, they lack the basic information on how net-zero housing can reduce GHG emissions and improve sustainability. As shown in Figure $9,22.41 \%$ of the survey participants were not sure whether NZE homes are one of the mechanisms contributing to the green environment.

Significantly more than $50 \%$ of the survey participants were not quite interested in purchasing NZE homes. This is linked with their shortfall of knowledge and understanding of the concept of NZE homes. A good understanding of the benefits of NZE homes may contribute positively to a growing interest in such homes. On the other hand, NZE homes have extra installations that would lead to additional costs on the home. The issue of extra cost may be clarified further while enhancing the public awareness of NZE homes. After knowing about NZE technology, most of the participants said they would be willing to pay more for NZE homes. Additionally, most of the participants indicated that they would be willing to install solar panels on their homes. This may be an indicator that more people are willing to purchase greener homes for a greener environment despite their high initial cost. However, the building experts observed that while the initial cost may be higher, the return on investment should be enough to offset this cost. Advocacy and public campaigns may enhance the public's understanding of NZE homes, especially the associated benefits. The research findings point to the fact that increased awareness of the benefits of NZE homes may increase the public's interest in these homes. Consequently, this will open more market as demand increases and help save the environment from harmful GHG emissions. The 
government, academic institutions, and the industry should work harmonically together to increase the public awareness of NZE homes.

\section{Conclusions and Recommendations}

The study sought to find the obstacles associated with NZE homes, realize the public awareness of these homes, and recommend ways in which their popularity can be achieved.

\subsection{Conclusions}

Research findings revealed that there are various challenges associated with the construction of NZE homes, including insufficient technological experts, the deficient governmental and institutional supports, and the lack of public knowledge, stated broadly. The shortage of enough professionals who understand the NZE technology exists in the GTA construction industry. The construction of an energy-efficient building calls for interdisciplinary collaboration. Finding experts from the different disciplines is an uphill task. The lack of public awareness is also hindering the growth of NZE homes in the GTA. In these scenarios, the building experts (interviewees) have various opinions on what should be done and how it should be done to overcome the visible obstacles to the development of NZE homes.

The interviewed building experts mentioned that technological barriers are the most critical obstacles to developing NZE homes in the GTA. The lack of technological knowhow is hindering the promotion of NZE homes. This is because the idea of NZE homes is relatively new and the availability of skilled professionals educated with NZE building technology is currently limited in the construction industry. To promote NZE homes, technological barriers must be removed urgently. Architects and engineers should be well-educated about NZE building technology before designing and constructing NZE homes. The manufacturers should also be trained to make energy-saving building materials, products, and appliances as well as to create energy-producing elements. In addition, the trade people need to be trained in advance for the installation of different energy-producing components and systems on NZE homes. There should also be standardized measures to evaluate the performance of NZE homes.

Next to technological barriers, the lack of governmental and institutional supports plays a critical role against the promotion of NZE homes. Many survey participants residing in the GTA think that they will not get governmental support to purchase an NZE home. In this perspective, the interviewed building experts indicated that the government should be adequately supportive to individuals who are interested in purchasing NZE homes. At present, there are no incentive and rebate programs in the GTA for buying new NZE homes, although some financial supports are available for energy retrofitting of old homes. The federal and municipal policy frameworks should also be conducive to the construction of NZE homes. The lack of good policies for developing renewable energy may undermine the progress of NZE houses.

Lastly, the lack of the public awareness is also acting against the advancement of NZE homes. At present, the public awareness of NZE homes is seriously lacking in the GTA. Both interview and survey results disclosed that the GTA public lacks enough awareness of NZE homes, although construction professionals and consultants know about these homes. Many survey participants were not quite familiar with NZE homes and they were not interested in purchasing these energy-efficient homes. This is because they were not aware of the benefits of living in an NZE home. Such lack of knowledge is limiting the sale of NZE homes. The popularity of NZE homes depends to a greater extent on the knowledge that the public have towards them. The lack of the public awareness may lead to a poor level of interest in NZE homes despite their perceived benefits. The government, academic institutions, and the industry all have an important role to increase the public awareness of NZE homes.

Many residents in the GTA are financially capable of purchasing a new NZE home, having an annual income above $\$ 75,000$. They also have the capability to install solar 
panels on old homes for energy efficiency. Most of the survey participants residing in the GTA became willing to pay more for NZE homes and install solar panels on old homes after knowing their benefits. They agreed that NZE homes are environmentally friendly. These findings suggest that more public awareness of NZE homes is required to enhance the growth of such homes in the GTA.

\subsection{Recommendations}

The government, the academic institutions and centers, and the industry should work together to remove technological barriers, which are the most critical obstacles on the way of NZE homes for their growth in the marketplace. Skilled professionals should be produced through necessary training to remove the technological barriers for constructing NZE homes. For this, academic institutions and training centers should take the leading role and the government should support them. In addition, the manufactures ought to understand the essence of NZE building technology and ensure the availability of the materials and products required for NZE homes. Necessary tools, such as equipment and software, required for analysis, design, and construction should also be obtainable for the creation of NZE homes.

The education sector should do more to incorporate newer NZE building technology into the curriculum to prepare students for the real world that they will be going to face after graduation. This sector needs to uptake any technological change as rapidly as it occurs to prepare the students to be adaptable in the ever-changing world, especially in the matters related to construction technology. Universities and colleges should produce technologically knowledgeable graduates who can work competently in the construction industry to build NZE homes.

More efforts need to be made for the public awareness of NZE homes. Different approaches to the creation and enhancement of the public awareness on matters related to NZE homes and green energy, in general, should be sought and implemented. The government should engage the green energy construction experts in policymaking and curriculum development to enhance the applicability and effectiveness of NZE homes. In addition, the government should offer incentives or rebates to encourage the public to purchase NZE homes. An incentive program should also be created for the developers to construct more and more NZE homes. Moreover, the federal and municipal policy frameworks should eradicate the capital and financial obstacles to the construction of NZE homes.

Additional studies should be carried out, although the survey and interview findings of the present study are coherent. More people should be surveyed, and more building experts should be interviewed to minimize the level of errors. Especially, further investigation should be conducted to find effective ways (e.g., technical means, training, knowledge dissemination, policies) of resolving various obstacles or challenges for the advancement of NZE homes.

Author Contributions: Conceptualization, G.M.; methodology, G.M. and M.S.; validation, G.M. and M.S.; formal analysis, G.M. and M.S.; investigation, G.M.; resources, M.S.; data curation, G.M.; writing-original draft preparation, G.M.; writing—review and editing, M.S.; visualization, G.M. and M.S.; supervision, M.S.; project administration, M.S. All authors have read and agreed to the published version of the manuscript.

Funding: This study was not funded by any external research institute. G.M. performed the study as a capstone industry research project to fulfill the requirements for her Honours Bachelor of Technology (Construction Management) degree.

Institutional Review Board Statement: Not applicable.

Informed Consent Statement: Not applicable.

Data Availability Statement: The data presented in this study are not publicly available. The data were gathered through survey and interviews. 
Acknowledgments: The authors are grateful to Angelo DelZotto School of Construction Management for giving the opportunity to conduct the research. They are also thankful to Tom Orman for his valuable instructions regarding technical writing.

Conflicts of Interest: The authors declare no conflict of interest.

\section{References}

1. Iyer-Raniga, U. Zero energy in the built environment: A holistic understanding. Appl. Sci. 2019, 9, 3375. [CrossRef]

2. Frappé-Sénéclauze, T.-P.; Kniewasser, M. The Path to "Net-Zero Energy" Buildings in BC: The Case for Action and the Role of Public Policy; Pacific Institute for Climate Solutions, University of Victoria: Victoria, BC, Canada, 2015; p. 24.

3. Toronto's 2018 Greenhouse Gas Emissions Inventory. Available online: https://www.toronto.ca/wp-content/uploads/2020/12/ 9525-2018-GHG-Inventory-Report-Final-Published.pdf (accessed on 9 February 2021).

4. Torcellini, P.; Pless, S.; Deru, M.; Crawley, D. Zero energy buildings: A critical look at the definition. In Proceedings of the 2006 ACEEE Summer Study on Energy Efficiency in Buildings, Pacific Grove, CA, USA, 14-18 August 2006; p. 12.

5. Pless, S.; Torcellini, P. Net-Zero Energy Buildings: A Classification System Based on Renewable Energy Supply Options; Technical Report: NREL/TP-550-44586; National Renewable Energy Laboratory (NREL): Golden, CO, USA, June 2010; p. 21.

6. Liu, Z.; Zhou, Q.; Tian, Z.; He, B.; Jin, G. A comprehensive analysis on definitions, development, and policies of nearly zero energy buildings in China. Renew. Sustain. Energy Rev. 2019, 114, 109314. [CrossRef]

7. $\quad$ Baden, S.; Fairey, P.; Waide, P.; de T'serclaes, P.; Laustsen, J. Hurdling financial barriers to low energy buildings: Experiences from the USA and Europe on financial incentives and monetizing building energy savings in private investment decisions. In Proceedings of the 2006 ACEEE Summer Study on Energy Efficiency in Buildings, Pacific Grove, CA, USA, 14-18 August 2006; p. 15.

8. Peterson, K.; Torcellini, P.; Grant, R. A Common Definition for Zero Energy Buildings; U.S. Department of Energy: Washington, DC, USA, September 2015; p. 22.

9. Hoque, S.; Iqbal, N. Building to net zero in the developing world. Buildings 2015, 5, 56-68. [CrossRef]

10. Albayyaa, H.; Hagare, D.; Saha, S. Energy conservation in residential buildings by incorporating passive solar and energy efficiency design strategies and higher thermal mass. Energy Build. 2019, 182, 205-213. [CrossRef]

11. Baetens, R. High performance thermal insulation materials for buildings. In Nanotechnology in Eco-Efficient Construction: Materials, Processes and Applications; Woodhead Publishing Limited: Cambridge, UK, 2013; pp. 188-206. [CrossRef]

12. Ohler, A.M.; Loomis, D.G.; Ilves, K. A study of electricity savings from energy star appliances using household survey data. Energy Policy 2020, 144, 111607. [CrossRef]

13. Shayan, M.E. Solar energy and its purpose in net-zero energy building. In Zero-Energy Buildings-New Approaches and Technologies; IntechOpen Limited: London, UK, 2020; p. 14.

14. Musall, E.; Cory, S.; Donn, M.; Garde, F.; Lenoir, A.; Voss, K.; Weiss, T. Net zero energy solar buildings: An overview and analysis on worldwide building projects. In Proceedings of the EuroSun 2020: 13th International Conference on Solar Energy for Buildings and Industry, Athens, Greece, 1-3 September 2020; p. 9.

15. Chang, Y.; Wei, Y. The utilization of renewable energy for low-carbon buildings. In Renewable-Energy-Driven Future: Technologies, Modelling, Applications, Sustainability, and Policies; Academic Press: Cambridge, MA, USA, 2021; pp. 289-309. [CrossRef]

16. Pettit, B.; Gates, C.; Fanney, A.H.; Healy, W.M. Design Challenges of the NIST Net-Zero Energy Residential Test Facility; NIST Technical Note 1847; National Institute of Standards and Technology (NIST), U.S. Department of Commerce: Gaithersburg, MD, USA, March 2015; p. 71.

17. Todd, J.; Chen, J.; Clogston, F. Creating the Clean Energy Economy: Analysis of the Net-Zero Energy Home Industry; International Economic Development Council (IEDC): Washington, DC, USA, 2013; p. 140.

18. Abdellah, R.H.; Masrom, M.A.N.; Chen, G.K.; Mohamed, S.; Omar, R. The potential of net zero energy buildings (NZEBs) concept at design stage for healthcare buildings towards sustainable development. IOP Conf. Ser. Mater. Sci. Eng. 2017, $271,012021$. [CrossRef]

19. Quinn, E. Green acres: Developer to build 'zero-energy' homes in New Paltz. New Paltz Times, 7 August 2008.

20. Torcellini, P.; Pless, S.; Lobato, C. Main street net-zero energy buildings: The zero-energy method in concept and practice. In Proceedings of the ASME 2010 4th International Conference on Energy Sustainability, Phoenix, AZ, USA, 17-22 May $2010 ;$ p. 12.

21. NetZero: Future Building Standards. 2020. Available online: https://www.nrcan.gc.ca/energy-efficiency/energy-efficiencyhomes/buying-energy-efficient-new-home/netzero-future-building-standards/20581 (accessed on 2 February 2021).

22. Net Zero Energy (NZE) Housing. 2015. Available online: https://www.nrcan.gc.ca/energy/efficiency/data-research-andinsights-energy-efficiency/housing-innovation/net-zero-energy-nze-housing/5131 (accessed on 5 January 2021).

23. Zhang, Y.; Wang, H.; Gao, W.; Wang, F.; Zhou, N.; Kammen, D.M.; Ying, X. A survey of the status and challenges of green building development in various countries. Sustainability 2019, 11, 5385. [CrossRef]

24. City of Toronto. Zero Emissions Buildings Framework; The Planning Division, the City of Toronto: Toronto, ON, Canada, March 2017. 
25. Netzero Home: The Ultimate in Comfort and Efficiency. 2021. Available online: https://www.chba.ca/CHBA/BuyingNew/ Net-Zero-Homes.aspx/\#: \{\}:text=Net\%20Zero\%20Homes\%20produce \%20as, the \%20remaining\%20energy $\% 20$ they $\% 20$ need. \&text=The \%20result \%3A\%20exceptional\%20energy\%20performance,at\%20the\%20forefront $\% 20$ of $\% 20$ sustainability (accessed on 6 February 2021).

26. Bowerbank, A.; Agustin, K.; Arsenijevich, N. The Journey to Netzero Energy; A Lessons Learned Report; EllisDon Corporation: Mississauga, ON, Canada, 2018; p. 48.

27. The Beaches Net-Zero Home. 2021. Available online: https:/ / craigrace.com/portfolio/the-beaches-net-zero-home/ (accessed on 1 February 2021).

28. Piderit, M.; Vivanci, F.; van Moeseke, G.; Attia, S. Net-zero buildings-A framework for an integrated policy in Chile. Sustainability 2019, 11, 1494. [CrossRef]

29. Are Net-Zero Homes the Future of Ontario Living? 2016. Available online: https://www.tvo.org/article/are-net-zero-homesthe-future-of-ontario-living (accessed on 31 January 2021).

30. LEED®Canada for Homes. 2021. Available online: https://www.cagbc.org/CAGBC/Programs/LEED/LEED_Canada_Rating_ System/Homes/Leed_Canada_for_Homes.aspx (accessed on 12 February 2021).

31. Energy/GHG \& Resilience for Low-Rise Residential Development. 2021. Available online: https://www.toronto.ca/citygovernment/planning-development/official-plan-guidelines/toronto-green-standard/toronto-green-standard-version-3/lowrise-residential-version-3/energy-ghg-resilience-for-low-rise-residential-development/ (accessed on 9 February 2021).

32. Energy/GHG \& Resilience for Mid to High-Rise Residential \& Non-Residential Development. 2021. Available online: https:/ / www.toronto.ca/city-government/planning-development/official-plan-guidelines/toronto-green-standard/torontogreen-standard-version-3/mid-to-high-rise-residential-all-non-residential-version-3/energy-ghg-resilience-for-mid-to-highrise-residential-all-non-residential-development/ (accessed on 10 February 2021).

33. McVey, I.; Farbridge, K.; Calvert, K. On the Path to Net-Zero Communities: Integrating Land Use and Energy Planning in Ontario Municipalities; Community Energy Knowledge-Action Partnership (CEKAP): Toronto, ON, Canada, May 2017 ; p. 86.

34. Wills, A.; Beausoleil-Morrison, I.; Ugursal, I. Evaluation of source net-zero performance for residential community-scale retrofit photovoltaic systems in Canadian locations. In Proceedings of the eSim 2016 Building Performance Simulation Conference, Hamilton, ON, Canada, 3-6 May 2016; p. 10.

35. Bonds-Raacke, J.M.; Raacke, J.D. Research Methods: Are You Equipped? 2nd ed.; Kendall Hunt Publishing: Dubuque, IA, USA, 2014.

36. Martinez-Molina, A.; Boarin, P.; Tort-Ausina, I.; Vivancos, J.-L. Post-occupancy evaluation of a historic primary school in Spain: Comparing PMV, TSV and PD for teachers' and pupils' thermal comfort. Build. Environ. 2017, 117, 248-259. [CrossRef]

37. Census Profile, 2016 Census. Toronto (Census Metropolitan Area), Ontario and Ontario (Province). 2017. Available online: https:/ / www12.statcan.gc.ca/census-recensement/2016/dp-pd/prof/details/page.cfm?Lang=E\&Geo1=CMACA\&Code1 $=535 \&$ Geo2 $=$ PR\&Code2=35\&Data=Count\&SearchText=Caledon\%20East\&SearchType=Begins \&SearchPR=01\&B1=All $($ accessed on 1 February 2021).

38. Cochran, W.G. Sampling Techniques, 3rd ed.; John Wiley \& Sons: New York, NY, USA, 1977; p. 448.

39. Krejcie, R.V.; Morgan, D.W. Determining sample size for research activities. Educ. Psychol. Meas. 1970, 30, 607-610. [CrossRef]

40. Bartlett, J.E.; Kotrlik, J.W.; Higgins, C.C. Organizational research: Determining appropriate sample size in survey research. Learn. Perform. J. 2001, 19, 43-50.

41. Naing, L.; Winn, T.; Rusli, B.N. Practical issues in calculating the sample size for prevalence studies. Arch. Orofac. Sci. 2006, 1, 9-14.

42. Diez, D.; etinkaya-Rundel, M.; Barr, C.D. OpenIntro Statistics, 4th ed.; OpenIntro: San Francisco, CA, USA, $2019 ;$ p. 422.

43. Fellows, R.; Liu, A. Research Methods for Construction, 3rd ed.; Wiley-Blackwell Publishing: Hoboken, NJ, USA, 2008 ; p. 322.

44. Mustafa, F.A. Performance assessment of buildings via post-occupancy evaluation: A case study of the building of the architecture and software engineering departments in Salahaddin University-Erbil, Iraq. Front. Archit. Res. 2017, 6, 412-429. [CrossRef]

45. Taherdoost, H. Determining sample size: How to calculate survey sample size. Int. J. Econ. Manag. Syst. 2017, 2, $237-239$.

46. Petersen, J.S.; Allman, P.H. The margin of error on damages calculations based on sample survey data in class action wage and hour cases. J. Leg. Econ. 2019, 25, 139-155.

47. Liang, Z.; Shen, H. Determining sample size for building energy consumption surveys using statistical theory. Energy Build. 2012, 47, 533-539. [CrossRef]

48. Fox, N. Using Interviews in a Research Project; The NIHR RDS for the East Midlands/Yorkshire \& the Humber: Nottingham, UK; Sheffield, UK, 2009; p. 39.

49. Galvin, R. How many interviews are enough? Do qualitative interviews in building energy consumption research produce reliable knowledge? J. Build. Eng. 2015, 1, 2-12. [CrossRef]

50. Bavaresco, M.V.; D'Oca, S.; Ghisi, E.; Lamberts, R. Methods used in social sciences that suit energy research: A literature review on qualitative methods to assess the human dimension of energy use in buildings. Energy Build. 2020, 209, 109702. [CrossRef]

51. Moser, C.A.; Kalton, G. Survey Methods in Social Investigations, eBook ed.; Taylor and Francis: London, UK, 2017 ; p. 576.

52. Biemer, P.P. Total survey error: Design, implementation, and evaluation. Public Opin. Q. 2010, 74, 817-848. [CrossRef]

53. CaGBC. Zero Carbon Buildings Framework: For Commercial, Institutional, and Multi-Family Buildings in Canada; Canada Green Building Council (CaGBC): Ottawa, ON, Canada, November 2016; p. 48. 
54. McNabb, N. Strategies to Achieve Net-Zero Energy Buildings: A Framwork for Future Guidelines; Workshop Summary Report, NIST Special Publication 1140; National Institute of Standards and Technology: Gaithersburg, MD, USA, 2013; p. 48.

55. Feng, W.; Khanna, N.Z.; Fridley, D.; Ke, J.; Ke, H.; Zhou, N. Impact analysis of developing net zero energy buildings in China. In Proceedings of the 2016 ACEEE Summer Study on Energy Efficiency in Buildings, Pacific Grove, CA, USA, 21-26 August 2016; p. 14.

56. Bahaj, A.S. Photovoltaic roofing: Issues of design and integration into buildings. Renew. Energy 2003, 28, 2195-2204. [CrossRef]

57. Jung, D.K.; Lee, D.H.; Shin, J.H.; Song, B.H.; Park, S.H. Optimization of energy consumption using BIM-based building energy performance analysis. Appl. Mech. Mater. 2013, 281, 649-652. [CrossRef]

58. Energy-Efficient Housing Made More Affordable with Mortgage Loan Insurance. 2021. Available online: https://www cmhc-schl.gc.ca/en/finance-and-investing/mortgage-loan-insurance/the-resource/energy-efficient-housing-made-moreaffordable-with-mortgage-loan-insurance (accessed on 11 February 2021).

59. City Council Declares Climate Emergency and Commits to Accelerating Action to Address Climate Change. 2021. Available online: https:/ / wx.toronto.ca/inter/it/newsrel.nsf/11476e3d3711f56e85256616006b891f/49a94e0367747ad58525848700578157 ?OpenDocument (accessed on 2 February 2021).

60. City of Toronto Launches BetterHomesTO to Help Residents Shift to 'Net Zero' Homes. 2021. Available online: http:/ / wx.toronto. ca/inter/it/newsrel.nsf/7017df2f20edbe2885256619004e428e/a2c6f3fa7e7b3047852584a9005c0bb1?OpenDocument (accessed on 1 February 2021). 